ELORE (ISSN 1456-3010), vol. $14-1 / 2007$.

Julkaisija: Suomen Kansantietouden Tutkijain Seura ry.

[http://www.elore.fi/arkisto/1_07/han1_07.pdf]

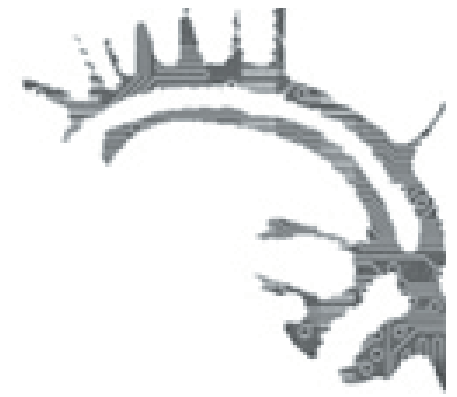

\title{
Perspectives On The Narrative Construction OF EMOTIONS
}

\section{$\underline{\text { Kirsi Hänninen }}$}

\section{INTRODUCTION}

In this article I will discuss some discursive and narrative approaches to the study of emotions in first person narratives. I will start by focusing on discursive psychology and notions of Derek Edwards, Rom Harré, and Grant Gillett and continue introducing two narrative theorists, Alan Palmer and Dorrit Cohn and their approaches to the construction of fictional minds. I will discuss Cohn's model of consonant and dissonant self-narration and give the reader an example how the model can be used in analyzing a narrative about a supernatural experience.

Let us begin by asking what emotion is. I consider Keith Oatley's definition of emotion useful for this article: "An emotion is a psychological state or process that functions in the management of goals. It is typically elicited by evaluating an event as relevant to a goal; it is positive when the goal is advanced, negative when the goal is impeded" (Oatley 1999, 273). One can distinguish emotional states based on their duration: a conscious emotion lasts minutes or hours, and a mood has similar bases to an emotion but lasts longer. When they last even longer, they can be seen as dispositions and personality traits, which last for years or even a lifetime. (Oatley 1999, 273-275.) Both shorter and longer emotions are signals to ourselves and others. They steer people towards things they evaluate as worthwhile in their projects and away from what would be deleterious. They are also signals to others since even though people can not notice inner feelings of each others, they notice the emotions. (Oatley 2004, 16.)

Emotions, their origins and their expressions can be approached from several directions, for example biological, neurophysiological, philosophical and cognitive. I consider the social-constructionist approach most suitable for my research. According to this approach, culture determines what emotions can be expressed and what kinds of expressions are acceptable. In addition, culture influences which situations lead to particular emotions. The social-constructionist approach to emotions does not reject 


\section{Perspectives On The Narrative Construction Of Emotions}

the idea that there is at least some innate component in emotions, but it emphasizes that each culture has its own evaluations that call forth emotions and its own emotions that match its social practices. (Johnson-Laird \& Oatley 2000, 467-472.)

\section{DisCURSIVE PSYCHOLOGY AND EMOTIONS}

When discussing the narrative construction of emotions, I draw on ideas from the field of discursive psychology, which deals with how people talk about emotions, how they use emotion categories when talking about things, and how emotional discourse performs social actions. From this perspective emotions should not be thought of merely as physiological reactions to stimuli nor abstract entities but as actual moments of emotional feelings and displays in a definite cultural setting. Each vocabulary expresses a local taxonomy and theory of emotions, an emotionology, that is, the way people identify, classify and recognize emotions. According to Harré and Gillett, three different topics are addressed in emotion vocabularies: moral (e.g. "jealousy"), aesthetic (e.g. "delight"), and prudential (e.g. "dread"). Emotion displays and feelings are discursive acts, based on bodily reactions but meanings defined by their role in the discursive interactions of members of particular culture. (Harré and Gillett 1994, 148, 160-161.) Thus, according to Derek Edwards, "Emotion discourse is an integral feature of talk about events, mental states, mind and body, personal dispositions, and social relations" (Edwards 1997, 170). Discursive psychology is broadly compatible with social constructionist work. No clear distinction is made between emotion 'discourse' and emotions 'themselves'. What emotions are is relative to what emotions are taken to be, how they are conceptualized, talked about, and interpreted. Emotions 'themselves' are socially and historically defined. (Edwards 1997, 179-180.)

Discourse of emotions refers to the use of verbal formulae for actions, feelings and motives, with regard to interpersonal judgments and attitudes, located within local moral orders of authority and responsibility. Edwards notes that a key feature of emotion discourse is its deployment inside narrative and rhetoric. Emotion terms emerge not only as unique descriptions of certain acts or reactions, but as parts of interrelated sets of terms that implicate each other in narrative sequences and rhetorical contrasts. Both narrative sequences and rhetorical contrasts are ways of talking about how discourse performs social actions at the moment of its production. These social actions include: constructing the sense of events, orienting to normative and moral orders, to responsibility and blame, and social evaluation. Emotion categories should not be considered merely as individual feelings or expressions. Neither is their discursive deployment reducible to a kind of detached, cognitive sense-making. Edwards concludes that emotion categories are discursive phenomena and need to be studied as such, as part of how talk performs social actions. (Edwards 1997, 187.)

In order to suggest how emotion discourse works in stories, Edwards presents a set of rhetorical positions and contrasts that can structure narrative discourse. 


\section{KIRSI HÄNNINEN}

For example, emotions can be seen irrational versus rational; cognitively grounded and/or cognitively consequential; event-driven versus dispositional; passive reaction (unaccountable feelings) or controllable actions (what you accountably do); internal states (private feelings) versus external behaviour (expressions); spontaneous versus externally caused; honest versus faked and natural versus moral emotions. (Edwards 1997, 193-194.)

\section{EMOTIONS AND THE CONSTRUCTION OF FICTIONAL MINDS}

I extend Edwards' work by synthesizing his account with Alan Palmer's research on the importance of the emotions in the construction of fictional minds. I am referring to his book Fictional Minds (2004). Palmer is a narratologist who situates himself in post-classical narratology that rethinks and recontextualizes classical models for narratological research. In particular, he emphasizes the need to examine how fictional minds work within the contexts of the storyworlds to which they belong. For Palmer, narrative fiction means the presentation of fictional mental functioning. Although Palmer focuses on the fictional mind, he uses real-mind discourses to investigate fictional minds. He notes that in addition to philosophy such as the philosophy of mind as well as the philosophy of action, his study makes use of other real-mind disciplines such as cognitive science, psychology, and psycholinguistics. Though Palmer acknowledges that his study is aimed primarily at specialists in literary theory in general and narrative theory in particular, he says he also tries to be helpful to scholars in other fields. (Palmer 2004, 4-8.)

Palmer argues the importance of the emotions in any analysis of the whole of the fictional mind. He notes that a lot of research has been done within narrative theory of fictional consciousness, but very little specifically on the emotions. He states that emotion is one of the more obvious ways in which our thoughts can become public. In general, Palmer examines how the fictional minds of characters are constructed by the narrator and the reader. That construction is essential, because narrative is the description of fictional mental functioning. (Palmer 2004, 12-26, 115.) He writes: "Readers create a continuing consciousness out of the isolated passages of text that relate to a particular character. In this way, we assemble what I call an embedded narrative: the whole of a character's various perceptual and conceptual viewpoints, ideological worldviews, and plans for the future considered as an individual narrative that is embedded in the whole fictional text." (Palmer 2004, 15.)

For Palmer, the whole mind includes emotions, as well as other functional aspects. "Emotions, cognitions, goals, action, context and so on, they all flow into one another until, the distinctions are difficult to maintain", Palmer states (Palmer $2004,117)$. The whole mind is a social mind too, since thoughts take place in a social context of action and interaction with other. The thoughts have purposive nature: They have motives, intentions, and they result in behavior and action. Palmer sees the thought report as the most suitable mode of presenting thoughts of the fictive 


\section{Perspectives On The Narrative Construction Of Emotions}

characters because most characters' thoughts take place in a social context of action and interaction with other. (Palmer 2004, 14-16, 77.) Thought report is the mode that Dorrit Cohn calls psycho narration in $3^{\text {rd }}$ person narration and self-narration in $1^{\text {st }}$ person narration. Palmer argues that thought report is especially suitable for presenting emotions, and he shows that analyzing thought report enables us to see that feelings are visible and public; emotions are inextricably linked with cognition; presentation of emotion plays a vital part in the creation of character and emotion passages have important teleological value. (Palmer 2004, 81, 113.)

Dorrit Cohn, considered to be one of the founders of contemporary poetics, is Ernest Bernbaum Professor of Literature at Harvard University. She is the author of Transparent Minds: Narrative Modes for Presenting Consciousness in Fiction (1978), The Distinction of Fiction, (1999) and of numerous articles on narrative poetics. In her book Transparent Minds: Narrative Modes for Presenting Consciousness in Fiction Cohn examines techniques for portraying the mental lives of fictional characters in the stream-ofconscious novel as well in other fiction. She states that though her discussion of the modes for rendering consciousness will be more literary than linguistic in its attention to stylistic, contextual, and psychological aspects, she takes linguistic criteria for her starting-point in naming and defining three basic techniques (Cohn 1978, 11). These narrative modes for presenting consciousness in third-person context are psychonarration (the narrator's discourse about a character's consciousness), quoted monologue (a character's mental discourse) and narrated monologue (a character's mental discourse in the guise of narrator's discourse). In first-person text psycho-narration becomes self-narration, and monologues either self-quoted, or self-narrated. She also names a first-person form of its own: autonomous interior monologue. (Cohn 1978, 14, 17.)

According to the model proposed by Cohn, the relationships between the narrating self and the experiencing self in first-person narratives can be placed on a sliding scale between dissonance and consonance. In the dissonant mode, the wise, distant and discursive self, the narrating self (narrating I), can move back and forth in time, turn back to past self/selves, contradict, explain, evaluate and analyze the thoughts, statements and actions of the experiencing self (experiencing I) and add information and opinions regarding past events. This narrating self sees the difference between ideals and realities, and moves between effects and causes. Opposite to this dissonant self-narration is the consonant self-narration where the narrating self reports what happened while adopting a vantage-point that is very proximate to experiencing self, and where it can even be difficult to distinguish between the experiencing self and the narrating self at all. Event may be focalized exclusively through the experiencing I, leading to an almost complete backgrounding of the narrating I. In consonant self-narration the psychological distance between experiencing and narrating selves is narrow and the narrating I does not draw attention to his/her opinions, judgments and hindsight. There is no self-exegesis, as Cohn puts it. (Cohn 1978, 145-158.) 
KIRSI HänNINEN

\section{How COHN'S MODEL CAN BE USED WHEN EXAMINING THE CONSTRUCTION OF EMOTIONS AND EMOTIONAL SELF IN NARRATIVES?}

My study, in general, examines how the supernatural has been constructed both as a revitalized and stigmatized cultural category and how people in contemporary Finland telling about supernatural experiences recognize and combat the stigmas related to the supernatural. It discusses the question of how supernatural, scientific and religious discourses intermingle and how certain kinds of knowledge and narratives become authoritative. I collected the material in Finland, in 2003-2004, and it consists of approximately 470 first-person retrospective accounts of encounters with supernatural beings such as angels, extraterrestrials, demons, ghosts and guardian spirits. Letters and e-mails were sent to me as responses to my inquiries published in newspapers. In the inquiry I asked people to answer such questions as "how did it feel to encounter a supernatural being?" and "how does it feel now when remembering the event?" The word supernatural refers here to an experience that the person considers as out of the ordinary world, mysterious or miraculous.

One possible approach to my research could be to examine the kinds of functions that descriptions of emotions serve in narratives about encounters between human beings and supernatural beings. In more detail, what kinds of emotions are related to supernatural experiences; how are the causes, states and consequences of these emotions constructed; how are the emotions used in the construction of narrating and experiencing selves, as well as other characters and narrated events and; how can we deal with the private/public distinction in public expressions of private experiences?

Here I present an example of how Cohn's model can be used to examine the narrative construction of emotions in written first-person factual narratives about supernatural experiences focusing attention on how this construction of an emotional self works in synergy with the sliding scale of consonant and dissonant self-narration. The excerption below is from a letter sent to me by a woman, born in 1959. I will present it in English here and the original Finnish version is in Appendix. Translation is my own.

Emphasis on narrating I:

[..] In January 1998 it happened that my brother was taken to the hospital and I told them that I can not come home since I had just started going to a computer course. Since I had already taken care of my things and their things, I continued joining the course. My brother and mother got angry and I had never felt worse than then. I was so afraid of what would happen back home but I didn't back off. There were no options, not anymore. My brother got his chance to let it go now that he didn't need to carry the burdens related to mother and home, and he died in two weeks. Our home that had been inhabited by our family nearly 100 years was suddenly empty. My mother 


\section{Perspectives On The Narrative Construction Of Emotions}

was sad, angry and very bitter in the nursery home close to our home. [..] It was the very rare moment when I thought, "I'm not going to get through this". [..]

Emphasis on experiencing I:

About one week after my brother's death and a week before the funeral, I was sitting on the couch in the morning, telephone in my arms, and listing things that I had already taken care of and things that I needed to take care of. Suddenly, I became conscious that there is SOMETHING on the left, about one and half meters away. [..] IT reached the ceiling, it was about one meter wide, like a solid pillar and IT emanated huge power, peace and trust. IT was very old, at least thousands of years, and very wise. IT walked with me for the next 6-7 weeks all the time. [..] I trusted it completely, from the first moment on: I wasn't alone anymore and everything would work out just fine. [..] After 6-7 weeks I realized one day IT is gone. [..] I understood, accepted it and thanked IT aloud for the visit and the help and I was sure I was never going to feel myself weak again.

Emphasis on narrating I:

I have lived a real human life after that, with all the sorrows and delights, feeling strong sometimes and weak sometimes! I have called IT many times when I have felt like being lost but IT doesn't come. You see: IT doesn't need to come. I am not lost, I am just lasy! [..] Now I just need to believe! And I do believe; I remind myself time to time about IT, and that thought gives me a buge feeling of strength and peace. [..]

In this narrative a supernatural experience works as a turning point of emotional life, and emotion discourse focuses on differences between the previous self and the current self. In Cohn's words, this is an example of dissonant self-narration. Throughout the whole letter the wiser analytical self moves back and forth in time, observes and explains the experiencing self and her development from worrying type of a person to a more relaxed person. This is also a good example of how emotions take place in social context and in interaction with others. In the beginning of the letter narrating I emphasizes the background of the supernatural experience. She explains how she had to take care of her mother and brother and the home, and how everything collapsed when her brother died. When she thought that she is not going to get through this, she met a being that appeared in the form of a pillar, an encounter that she briefly focalizes through experiencing I. She trusted in this pillar, her spiritual guide that is, survived the responsibilities, found inner peace and became a strong, relaxed, selfconfident person, evaluated through narrating I.

Both experiencing I and narrating I present various emotions. Narrating I begins the story by constructing the family-related, externally caused emotions: her fear on the one hand, and anger, sadness and bitterness of her mother and brother on the other hand. Experiencing I switches the focus on the actual encounter with the spiritual guide and the resulting certainty that she is never going to feel herself 


\section{KIRSI HÄNNINEN}

weak again. Narrating I returns and says she has felt both strong and weak, but emphasis the positive emotions of strength and peace that were the results of the encounter. Narrating I also connects belief and emotion: The positive emotions stay if she believes in the existence of the spiritual guide. Thus believing maintains the changes in personality traits. Though this example includes emotion talk, it is worth remembering that emotional descriptions are optional.

\section{SUPERNATURAL AND EMOTIONS: DEALING WITH DEVALUED CATEGORIES}

The supernatural is a category that breaks the general scheme of the modern western world and the order the world is supposed to possess. As David Hufford has pointed out, Protestant Christianity and Enlightenment skepticism have greatly influenced the way people consider the natural and the supernatural. On one hand, science rooted in the Enlightenment promotes the scientifically based explanations of natural phenomena and rejects the supernatural since it contradicts the natural laws. On the other hand, the religious organizations following the heritage of Protestant Reformation maintain the split between believing and observing. (Hufford 2005, 26.) The suppression, in the form of devaluing, continues and is constructed in different kinds of structures of social life. Supernatural experiences and experiencers are stigmatized, and narrators recognize that. Narrators may address the potential challenges by negotiating or denying the questions of hallucinations and mental health, illusions, dreams, and social status.

Emotions too are held to belong to the realm of body, irrational, unconscious, unintentional and uncontrolled - that is, to the devalued side of cultural categorization. (White 1993,31.) When constructing a narrative about one set of devalued experiences (the supernatural), why mention another devalued category (the emotions)? Perhaps because I asked them? Still, would not it be better to brush aside the irrational, the emotion descriptions? Here Edwards reminds us that "emotions are not just irrational, they are an integral part of rational accountability" (Edwards 1997, 194). Emotion descriptions can provide a contrast to rational thought but also a rationally sensible story of coherent and understandable reactions (Edwards 1997, 171).

Finally, the fact that narrators chose to share their supernatural experiences with a folklorist can be viewed as a decision to enter the public realm and the public debate on the reality of supernatural experiences. Both the emotions felt during the event and afterwards are portrayed as coherent and understandable reactions to supernatural experiences. This construction of emotion becomes the proof they offer up to the debate. For it is one thing to argue against the reality of a supernatural vision but quite another thing to contest someone's emotional reactions to such an experience. 


\section{Perspectives On The Narrative Construction Of Emotions}

\section{Appendix}

[..]Tammikuussa 1998 se tilanne sitten tuli, että veli tarvitsi välitöntä sairaalahoitoa, ja minä ilmoitin, etten tule apuun kotiin; olin juuri aloittanut atk-kurssin ja koska olin jo järjestänyt nïn omat kuin heidänkin asiansa, vein suunnitelmani täytäntöön. Äiti sunttui, veli suuttui, minulla oli pahempi olo kuin milloinkaan sydän kylmänä pelkäämässä, mitä kotona tapabtuu, mutta en perääntynyt. Vaibtoebtoja ei ollut, ei enää. Veli sai luvan luovuttaa päästyään kantamasta äidin ja kotipaikan asioita, ja kuoli parin viikon kuluttua. Liki 100 vuotta sukumme asuttama maapaikka oli äkekiä tybjillään ibmisistä. Äiti oli vihaisena, suruissaan ja erittäin katkerana hoivakodissa, aika lähellä kotipaik.kaa. [..] Tuli se harva kerta eteeni, että tuumasin itselleni: "Minä en selviä tästä." [..] Noin viikeon kuluttua veljen kuolemasta ja viikekoa ennen hautajaisia istuessani sohvalla puhelin sylissä vïvaamassa yli tehtyjä asioita ja kirjoittamassa unsia tebtäviä, siis aamupäivällä, havahduin äkkiä buomioon, että noin puolentoista metrin päässä minusta, etwvasemmalla, on JOKU. [..] SE oli kattoon asti pitkä, noin metrin levyinen, kuin byvin jykevä pilari, ja SE huokui ja säteili valtavaa voimaa, raubaa ja luottamusta. SE oli erittäin vanha, vähintään tuhansia vuosia, ja kaikkitietävän viisas. SE kulki mukanani seuraavat 1,5 kunkautta, 6-7 viikkeoa siis, joka betki. [..] Luotin siihen ensi betkestä alkaen täydellisesti: en ollut yksin ja kaikki asiat menisivät ehdottomasti kuin pitää. [..] Noin kunden-seitsemän viiken kuluttua eräänä päivänä tajusin, että SE on poissa. [..]Ymmärsin, byväksyin, kiitin SITÄ ääneen käynnistäja kaikesta avusta, ja olin aivan varma, etten ikinä enää elämässäni tunne itseäni voimattomaksi. Ihan oikeaa ihmiselämää olen elänyt senkin jälkeen iloineen ja suruineen, voimaintunnossa ja epätoivon alhossa! Olen monta kertaa kutsunut SITÄ, kun tunnen olevani hukassa, mutta ei SE tule. Katsos: SEN ei tarvitse. Minä en ole bukassa, vaan pelkästään laiska! [..] Nyt pitää vain uskoa! Ja minä uskon; muistutan itseäni aika-ajoin SIITÄ ja saan aina valtavan rauban ja voiman tunteen ajatuksesta. [..]

\section{REFERENCES}

COHN, DORRIT 1978: Transparent Minds. Narrative Modes for Presenting Consciousness in Fiction. Princeton: Princeton University Press.

EDWARDS, DEREK 1997: Discourse and Cognition. London: Sage Publications. HARRÉ, ROM \& GILLETT, GRANT: The Discursive Mind. Thousand Oaks: Sage Publications.

HUFFORD, DAVID J. 2005: Sleep Paralysis as Sprititual Experience. - Transcultural Psychiatry, 42(1): 11-43.

JOHNSON-LAIRD, P.N \& OATLEY, KEITH 2000: Cognitive and Social Construction of Emotions. - Lewis, Michael \& Haviland-Jones, Jeanette M (eds.), Handbook of Emotions. New York: The Guilford Press.[1993.] 
OATLEY, KEITH 1999: Emotions - Wilson, Robert A \& Keil, Frank C (eds.), The MIT Encyclopedia of Cognitive Sciences. Cambridge: MIT Press.

PALMER, ALAN 2004: Fictional Minds. Lincoln: University of Nebraska Press.

WHITE, GEOFFREY M. 1993: Emotions Inside Out: The Anthropology of Affect. - Lewis, Michael \& Haviland-Jones, Jeanette M. (eds.), Handbook of Emotions. New York: The Guilford Press.

MA Kirsi Hänninen is a Ph.D student at the Ohio State University, Department of Comparative Studies, and a folklore graduate student at the University of Turku. She is a student participant in Project Narrative at the Ohio State University. 